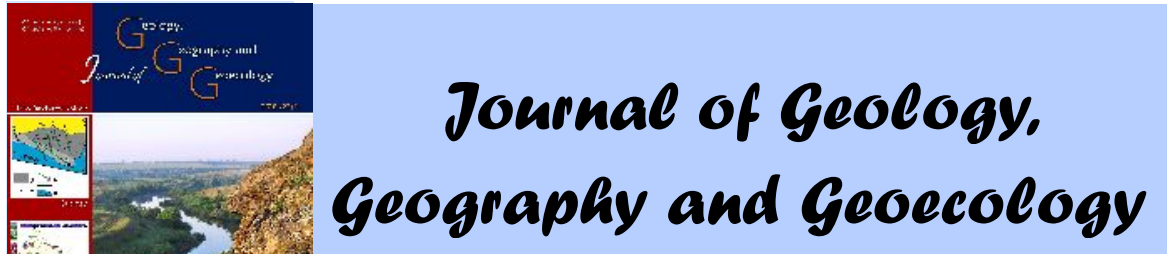

Journal home page: geology-dnu-dp.ua

\title{
Forecast landslide activity in the zones of technogenic geochemical anomalies of urban areas based on remote sensing data.
}

\section{T.P. Mokritskaya, D.A. Dovganenko}

Dnieper National University named after Oles Honchar, Dnipro,Ukraine, e-mail: mokritska@i.ua

Received 25.04.2018;

Received in revised form 09.05.2018;

Accepted 14.06.2018
Abstract. The analysis and forecast of landslide activity on the territories of cities is an actual task. Remote sensing methods are successfully used to solve a whole range of tasks: from classification to modeling. The possibilities of interpreting data are expanding. The processing involves standard methods of statistical research, methods of theories of fuzzy sets, pattern recognition, and others. This paper describes the experience of involving the method of grouping arguments into a prediction model. Firstly, an irregular time series of values of reflection coefficient on areas of active development of the landslide process is investigated. According to the results of the prognosis, it is proved that in the nearest future changes in solar activity (11 - year cycle) will not lead to activation of the process. Secondly, the forecast of the activation of the landslide process under the influence of man-made factors was fulfilled. The connection between the content of readily soluble salts in the pores of forest soils of the aeration zone and the values of the coefficient of reflection and. The model extends the possibilities of using the method of group consideration of arguments for mapping zones of landslide activity in sections of man-made geochemical anomalies. The analysis of the model shows that the connection is. In the future it is possible to determine certain values of salt content and values of reflection coefficients, which will be indicators of the probability of activating the landslide process in other conditions.

Keywords: forest, landslide, salinity, model

\section{рогноз зсувної ктивності в зон х техногенних геохімічних ном лій з будов них територій з м тері л ми дист нційного зондув ння.}

\footnotetext{
ніпровський н ціон льний університет імені леся онч р, нiпро, кр їн, e-mail: mokritska@i.ua
}

нот ція. н ліз і прогноз зсувної ктивності н територіях міст є кту льним з вд нням. етоди дист нційного зондув ння успішно з стосовуються для вирішення низки н уково-пр ктичних з вд нь: від кл сифік ції до моделюв ння. озширюються можливості інтерпретув ння д них, т к як до обробки з луч ються не тільки ст нд ртні методи ст тистичних досліджень, й методи теорій нечітких множин, розпізн в ння обр зів т інші. д ній роботі опис ний досвід з лучення методу групового обліку ргументів до створення прогнозної моделі зн чень коефіцієнт відбиття н ділянк х ктивного розвитку зсувного процесу н основі дослідження нерегулярної ч совій послідовності. ок з но, що н йближчим ч сом зміни сонячної ктивності (11 - річний цикл) ні будуть приводити до ктивіз ції процесу. ля вивчення і прогнозу ктивіз ції зсувного процесу під дією техногенних ф кторів вивчен зв'язок між вмістом легкорозчинних солей в пор х лесових грунтів зони ер ції, відповідними зн ченнями коефіцієнт відбиття і зн чення коефіцієнт н прилеглих зсувних ділянк х. трим но модель 3 лежності, що розширює можливості використ ння методу групового обліку ргументів для к ртув ння зон зсувної ктивності н діляHK х техногенних геохімічних ном лій. н ліз моделі пок зує, що можн визн чити кількісні критерії небезпеки як вміст солей і зн чення коефіцієнтів відбиття. е д сть можливість визн чити індик тори ймовірності ктивіз ції зсувного процесу. 
Introduction. In this paper, the variability of the water-salt regime in the aeration zone (1981-1983 and 1989-1990 yy.) was analyzed as one of the factors that increase the landslide activity (1983-2012) in the territory of city Dnipro. The geological structure of the aeration zone of the right-bank part of the city consists predominantly loess deposits, whose thickness reaches $25 \mathrm{~m}$. Within the study area was identified up to 155 sites of active landslide process. It is assumed that landslides develop mainly in loess sediments, are superficial and they have connection to different forms of relief (Zuska, 2014). There is spatio-temporal changes in the properties, composition and condition of loessial rocks occur both in the water saturation zone and in the aeration zone (Mokritskaya, 2012). The statistical correlation between the values of the reflection coefficient of the blue and near infrared spectra (satellites LANDSAT5 and LANDSAT-7) at the moment of 2009 (Mokritskaya, Dovganenko, Yaroshchuk, 2016) was discovered in the areas of active landslide process. Analysis of the trends in the content of light- and medium-insoluble salts in pore waters of loess-like loams under the influence of technogenic impacts from buildings and industrial facilities
(Mokritskaya, Fundaya, 2016) showed that in a short period of time (seven to ten years), the amount of sulphates and their variability was raised. The chloride content increased in the zone of influence of industrial structures. These changes may cause decries the strength of loess-like loam, and contribute to the further activation of the landslide process.

In this paper, was shown the relationship between the reflectance values (blue and near infrared spectra, the LANDSAT-7 satellite, six bands, 1981, 1989 and 1990) and the average salt content in the pore waters of rocks in the aeration zone. The content of an insoluble calcium sulfate $\mathrm{Ca}(\mathrm{HCO} 3) 2$ salt, a sparingly soluble salt of $\mathrm{Mg}(\mathrm{HCO} 3) 2$, and readily soluble salts of $\mathrm{Na}(\mathrm{HCO} 3), \mathrm{CaSO} 4, \mathrm{Mg} \mathrm{SO} 4$, $\mathrm{Na} 2 \mathrm{SO} 4, \mathrm{CaCl} 2, \mathrm{MgCl} 2, \mathrm{NaCl}$ was analyzed. The model of the relationship between the salt content in the rocks of the aeration zone and the values of the reflection coefficient probably can help to identify the zones of activation of the landslide process under the influence of technogenic geochemical anomalies. Sampling sites are distributed unevenly. Sample value is statistically reliable and representative (Figure 1).

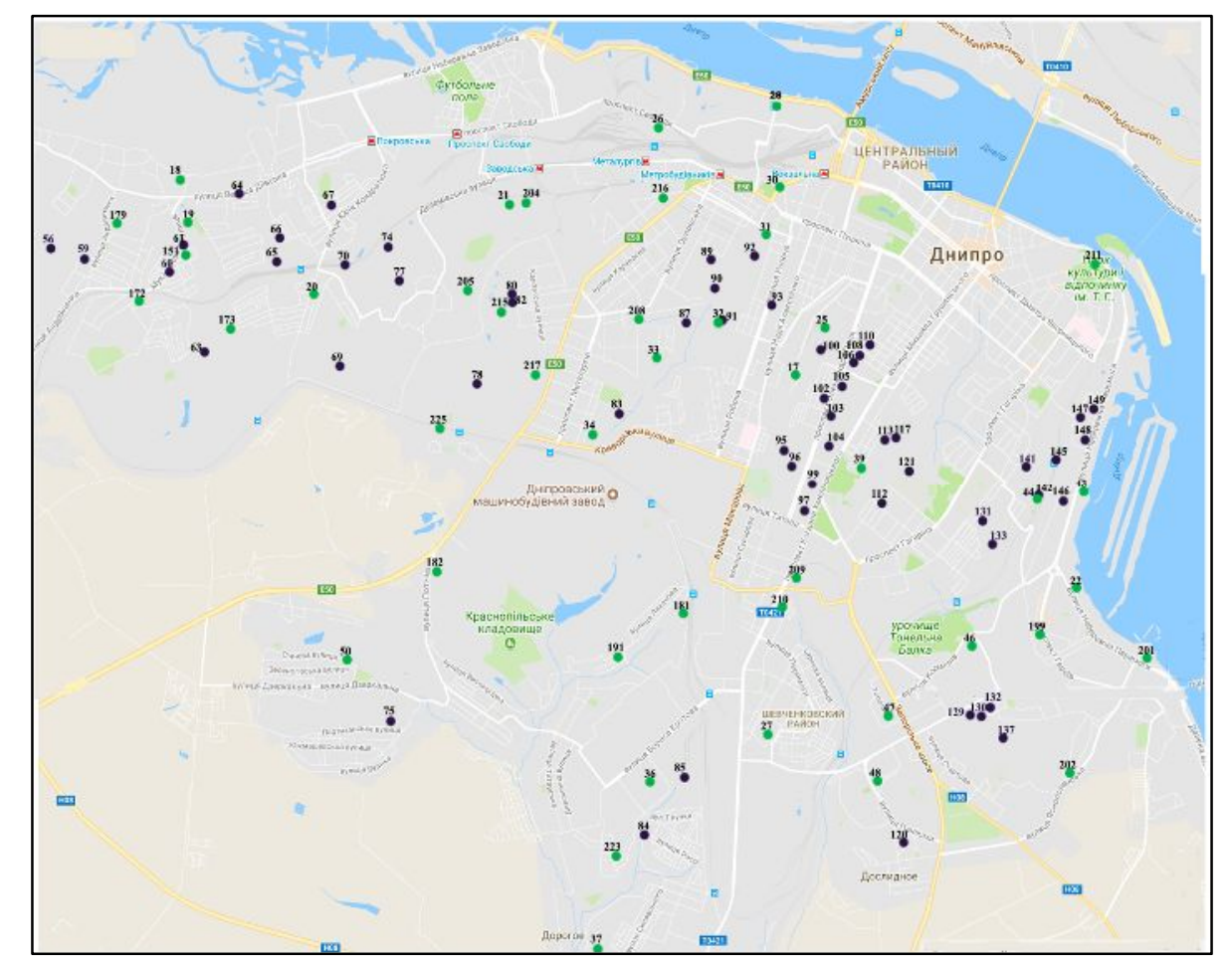

Fig. 1. Location of some landslide activation zones and ground sampling areas for determination of salt composition.

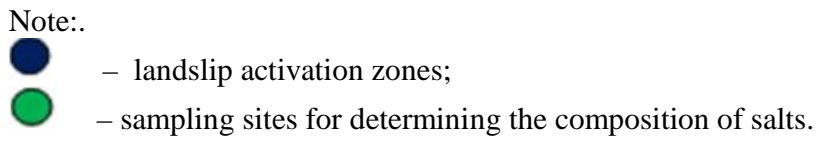


Material and methods of research. The database of the research include the observation data of the pore waters water-salt regime in the soils of the zone of aeration in the territory of Dnepropetrovsk (1981 1983 and 1989-1990, the CP "UkrJUggeology"), remote sensed data of the territory (LANDSAT- 5 and LANDSAT-7). For the mathematical processing of data, the author's used the Koryashkina L.S. "Projekt" software (Mokritskaya, Koriashkina, 2013) and standard applications of MS EXELL software. Inductive algorithms of the Group Method of Data Handling make it possible to automatically find interdependencies in the data, to choose the optimal structure of the model, and to increase the accuracy of existing algorithms. The choice of Group Method of Data Handling as a research tool can be justified by the following facts:

- there is optimal complexity of the structure of the model, adequate to the level of interference in the sample data;

- it is guaranteed to find the most accurate or unbiased model;

- the method does not miss the best solution during iterations (in a given class of functions);

- any nonlinear functions or characteristics that may have an effect on the output variable are use as input arguments;

- the method automatically finds interpreted relationships between values and selects effective input variables;

- the method uses information directly from the data sample and minimizes the impact of the a priori assumptions of the researcher on the modeled results;

- the method of group analysis of arguments is intended for solving problems of parametric, structural identification and forecasting, has a welldeveloped theory and numerous applications. The method is particularly effective for predicting on "short" samples.

The method uses ideas of self-organization and mechanisms of living nature - crossing (hybridization) and selection (selection).

Analysis of publications. Remote sensing data is widely used both for the identification and mapping of landslides, and for monitoring and analyzing the dynamics of landslides. For the specified purposes, surveys of visible, near infrared, thermal infrared, radio wave and ultraviolet zones of the spectrum are attracted. Based on the remote sensing materials, various applied problems are solved, from mapping, assessment of damage, risk to simulation of the process and study of its dynamics..

The paper (Cheng K. and al., 2004) is discovered the problem of landslides identification in the experimental territory $(333 \mathrm{~km} 2)$ of the National 90
Taiwan University. In the paper (Barlow J.and al., 2003) is shown the determination of the landslide separation walls in the Cascade Mountains (Canada), use of the segmentation procedure for images in combination with DEM analysis. Purnomo Y., Pinem F. (2010) developed a methodology for landslide hazard classifications based on statistical methods and GIS technologies. A summary of the experience of using GIS technologies for assessing the landslide hazard is demonstrated in the research (Saraf A. and al., 2009). Shabi H. And al., 2012, described the results of applying fuzzy-set analysis methods in assessing landslide hazard using LandsatETM +, SPOT, IRS-ID and other remote sense data.

The dynamics of the landslide process is indicated by the change in the reflection coefficient ( $\mathrm{J}$. Hervas and al., 2003). Remote sensing data can be used to simulate landslide processes (Mezughi T.H., and al., 2011). H. Kimura, Y. Yamaguchi (2000) analyzed the displacements at the site of the northern slope of the Azumayama volcano. Space images of high resolution make it possible to obtain more correct measures of the landslide hazard, since several quantitative indicators of dynamics can be calculated (Blesius L., Weirich F. 2009).

Some of the publications are devoted to methodological issues. Some procedures for image preprocessing are described in the work (Marcelino E. and al, 2009). The data for the landslide study of the coastal territory of the State of São Paulo (Brazil) used the satellite images of the Landsat-7 and SPOT4 satellites. The methodical part of the publication (Fernández T. and al., 2008) describes a method for automatically determining the offsets for multispectral images of Ikonos, Spot-5 and Landsat-7 in the Cordillera-Betika area (Spain). In opinion (Delacourt C. and al., 2007) aerial photography methods are optimal for studies of "rapid shifts" $(25 \mathrm{~cm} / \mathrm{s}$. And more); high-resolution satellite imagery can be used both for scientific purposes and to prevent landslide hazard.

Quantitative assessments of the effects of landslides caused by typhoons in the Shikhmen reservoir zone (Taiwan) were also obtained using GIS technologies and RS (Lin B. S., and al., 2011). Spectral satellite images (1996 to 2008 years) were studied, information on atmosphere precipitation was used too.

The use of remote research methods to predict the likelihood of landslide phenomena, karst-suffusion faults and other hazards is widely used in engineering-geological studies (D. Sudhakar, and all, 2013) and environmental-geological studies (Manibhushan and al., 2013). Remote sensing methods are an effective tool for monitoring and mapping 
landslides, as well as high-tech analysis of landslide hazard..

The results of the research. The Group Method of Data Handling (Mokritskaya, Koryashkina, 2013) was applied for creating the math model of the dependence of the coefficient of reflection on the previous values $(1988,1990,2003,2009,2010)$. This method (GMDH) was applied in the different areas for data analysis and finding values, forecasting and modeling of systems, image optimization and recognition. The data points of reflectance value, which has been defined in areas of active landslide processes in 2009, characterize the intensity of infrared spectrum in next dates: 18.05.1988, 18.02.1990, 23.04.2003, 26.06.2003, 29.08.2003, 26.06.2009, 25.03.2010, 24.01.2011. This sequence is irregular. We found out the equation of a linear trend of time series with the high value of the determination coefficient (using the number of months from the beginning of series as y-coordinate and a serial number as $\mathrm{x}$ coordinate). The next date of the sequence has been calculated as the prognosis value. The 24th 11-year cycle of solar activity has started in 2008 (Phillips T., 2008), the maximum of solar activity was reached at 2014. The cycle started in 2009 when we look at the other sources (Obzor, 2012). Prognosis values of reflectance value in the points of active development of the landslip process were calculated for 2017 (2017 is the year of decreasing of solar activity).

Math Model of prognosis values of the dependence of the coefficient of reflection of the nearinfrared spectrum based on the results of modeling of irregular time series (Group Method of Data Handling) was constructed (1):

$$
\begin{aligned}
& \quad=0,002+0,51 X_{6}-0,013 X_{6}^{2}-6,187 X_{5}-0,006 X_{5} X_{6}+0,024 X_{5} X_{6}^{2}+0,018 X_{5}^{2}- \\
& -0,007 X_{5}^{2} X_{6}-0,007 X_{5}^{2} X_{6}^{2}+0,733 X_{3}-0,182 X_{3} X_{6}+0,004 X_{3} X_{6}^{2}-0,088{ }_{3} X_{5}+ \\
& +0,053 X_{3} X_{5} X_{6}-0,007 X_{3} X_{5} X_{6}^{2}+0,011 X_{3} X_{5}^{2}-0,009 X_{3} X_{5}^{2} X_{6}-0,002 X_{3}^{2}- \\
& -0,001 X_{3}^{2} X_{5}+0,001 X_{3}^{2} X_{5} X_{6}-1,152 X_{1}-0,005 X_{1} X_{6}+31,799 X_{1} X_{5}+0,145 X_{1} X_{5} X_{6}- \\
& -0,001 X_{1} X_{5} X_{6}^{2}-0,092 X_{1} X_{5}^{2}+0,036 X_{1} X_{5}^{2} X_{6}+0,034 X_{1} X_{5}^{2} X_{6}^{2}-0,009 X_{1} X_{3}+ \\
& +0,003 X_{1} X_{3} X_{6}+0,258 X_{1} X_{3} X_{5}-0,079 X_{1} X_{3} X_{5} X_{6}-0,055 X_{1} X_{3} X_{5}^{2}+0,046 X_{1} X_{3} X_{5}^{2} X_{6}
\end{aligned}
$$

Here is a prognosis value of the coefficient of reflection;

1 - values of the coefficient of reflection in the given points in 18.05.1988

3 - the same in 23.04.2003

5 и $\quad 6$ - the same in 29.08.2003 and 26.06.2009

The prognosis values change from 0,168 to 0,302 (table 1). Maximum values are found in the points where the probability of the landslide activity is confirmed by the results of regression analysis of the coefficients of blue and near-infrared canals and the inaccuracy in this points is minimal. We have proved earlier that the coefficient of reflection takes extreme high value in the points of active development of the landslip process in time of changing the cycles of solar activity. In this work values of the coefficient of reflection which are bigger than 0.4 is used as indicators of the landslide activity. In general, results of modeling values of the coefficient of reflection in points of actively developing the landslide process shows that the whole reduction of the landslide activity which is caused by the 11-year cycle of solar activity is possible in the nearest future.

After statistical analysis of the values of coefficients of blue and near-infrared canals in points where the consistency of salts in rocks of aeration zones is known, we can infer that the correlation link between the values of coefficient and consistency of salts changes from weak to strong. Values of the coefficient of rank correlation changes from 0.02 to 0.94 . Visual analysis of the average values points out on the weak link between the tendencies of changing the reflection coefficient mentioned canals and salts consistency in \% (fig. 2).

Table 1. Prognosis values of the reflection coefficient (blue canal, 2017).

\begin{tabular}{|c|c|c|c|}
\hline № of point & \multicolumn{2}{|c|}{ The method of prognosis of the reflection coefficient } & \multirow{2}{*}{ Relative error, \% } \\
\hline & $\begin{array}{c}\text { Group Method of Data } \\
\text { Handling }\end{array}$ & 0,2577 & 33 \\
\hline 102 & 0,1938 & 0,2592 & 30 \\
\hline 103 & 0,1988 & 0,2592 & 26 \\
\hline 104 & 0,2394 & 0,2638 & 1 \\
\hline 105 & 0,2095 & 0,2983 & 43 \\
\hline 106 & 0,2956 & 0,3058 & 54 \\
\hline 108 & 0,3018 & 0,2668 & 37 \\
\hline 113 & 0,1867 & 0,2577 & \\
\hline 117 & 0,1677 & 0,2998 & \\
\hline
\end{tabular}


Applying the Group Method of Data Handling gave us a possibility to perform the creation of the model of the relation between prognosis values of reflection coefficient of blue spectral canal in points of landslip activation from average values of hard- and easysoluble salts (fig.3) and corresponded values of reflection coefficient using software Projekt (Mokritskaya, Koryashkina, 2013). The analysis of the model shows, that increasing of easy-soluble salts $\mathrm{Mg} 2 \mathrm{SO} 4$ leads to increasing of values of the re- flection coefficient at places with active landslip process. The impact of readily soluble salt $\mathrm{NaCl}$ is more difficult than the previous one because values of the coefficient will increase only when the balance between salt consistency and product of numbers is broken. The equations similar to this one let us find out the critical values of consistency of salts and corresponding coefficients which will reduce the allowable range of the coefficient in the areas of active landslide process.

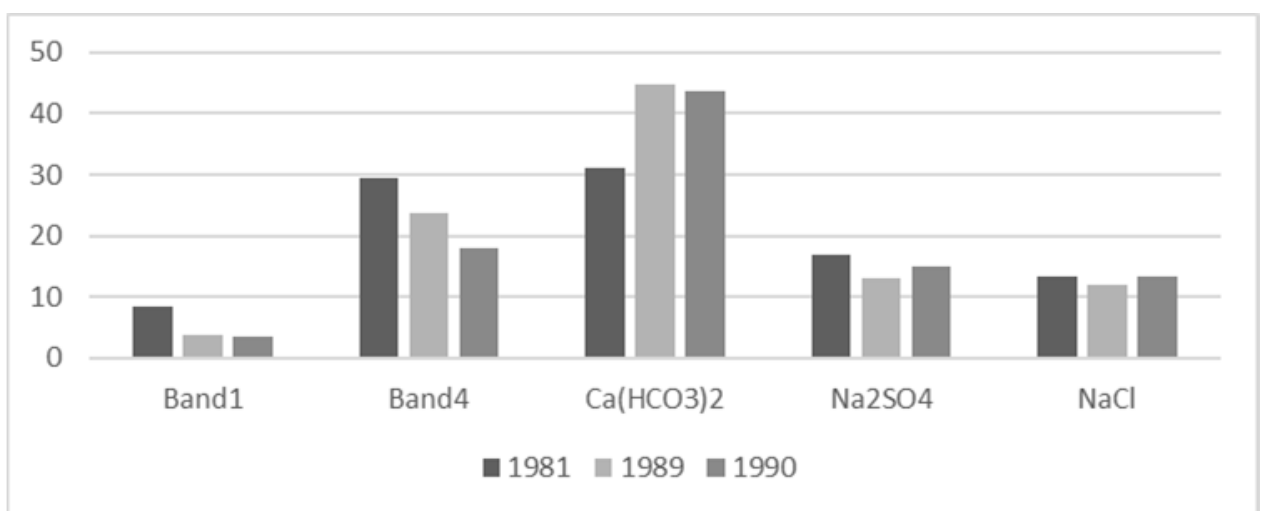

Fig.2. Dynamics of the average values of the reflection coefficients and salts consistency (in percentages) in aeration zone rocks (Dnipro, 1981 - 1990).

Note for picture 2:

1. Average value of a reflection coefficient: band 1 - blue canal, band 4 - near-infrared canal;

2. Average salts consistency in percentages: $\mathrm{Ca}\left(\mathrm{HCO}_{3}\right)_{2}, \mathrm{Na}_{2} \mathrm{SO}_{4}, \mathrm{NaCl}$.

3. Values of the reflection coefficient are increased in 100 times for making the presentation in the figure above clearer.

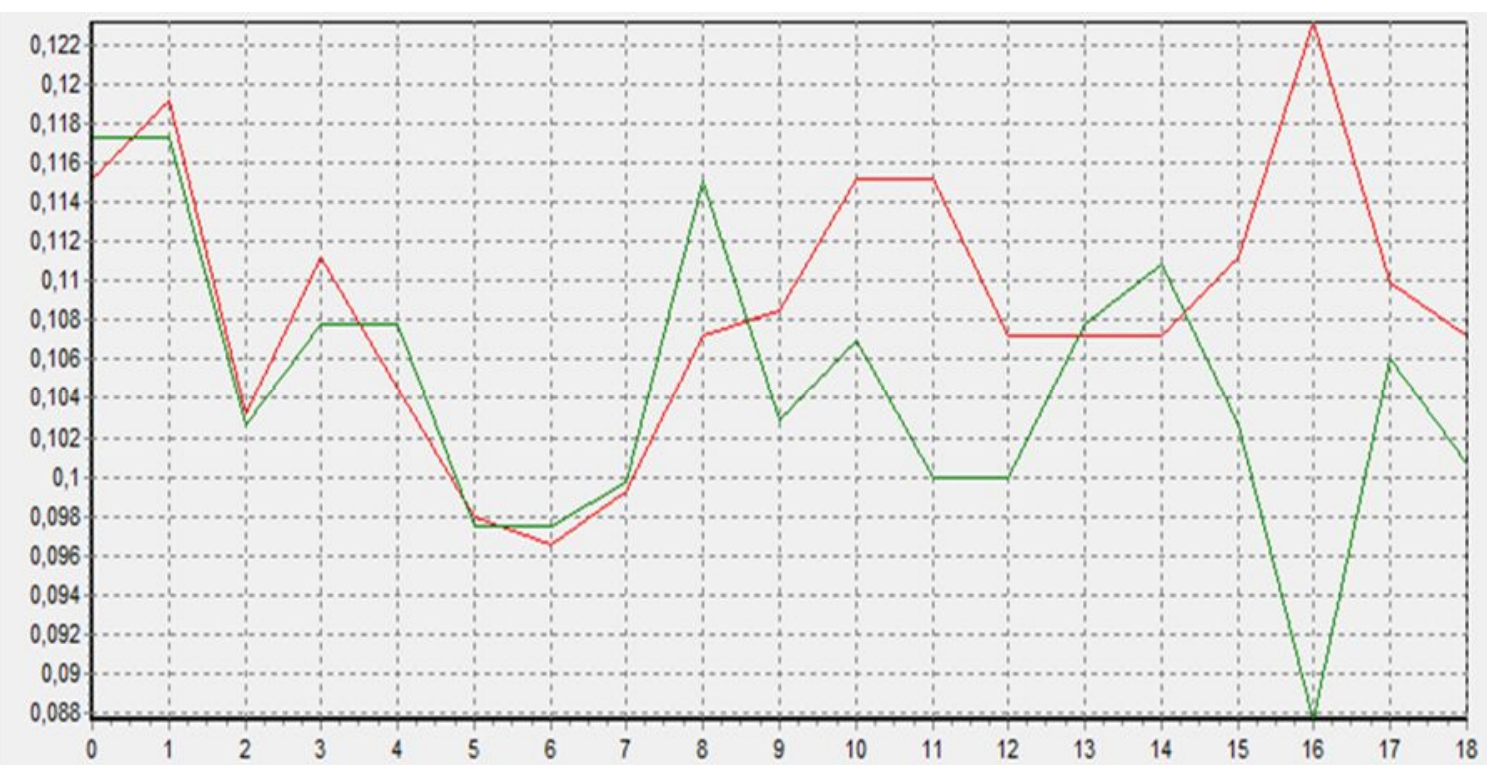

Fig. 3. The results of modeling the relation between values of the reflection coefficient and consistency of salts in the ground pores.

Note for the fig. 3:

- approximation function :

- statistical information. 
The model of the link between values of the reflection coefficient and the consistency of salts in the ground pores in aeration zone obtained as next equation (2):

$$
\begin{gathered}
\text { band } 1=0,009 \mathrm{Mg}_{2} \mathrm{SO}_{4}+0,007 \mathrm{NaCl}- \\
-0,179 \text { band } 4-0,013 \text { band } 4 \mathrm{NaCl}
\end{gathered}
$$

band1 - predictive value of the reflection coefficient (the indicator of the possible landslip activity);

band 4 - the value of the reflection coefficient in point with the known average consistency of salts in grounds of aeration zones;

$\mathrm{Mg}_{2} \mathrm{SO}_{4}$ and $\mathrm{NaCl}$ - the average consistency of mentioned salts in ground pores in percentages.

\section{Conclusions:}

- The activation of landslide processes due to the influence of natural factors (11-year cycle of solar activity), is unlikely in the near future.

- Decreasing of soil strength in the aeration area (due to the changes of salts content in the soil's pores) may influence the activity of landslide processes.

- The resulting equation can be used as a hazard indicator for the forecast of landslide activity in built-up areas.

\section{References}

Monitorynh heolohichnoho seredovyshcha po terytoriyi Dnipropetrovs koyi oblasti. 2006. Zvit KP «Pivdenukrheolohiya», 2001 - 2006, 6 t., [Monitoring of the geological environment in the Dnipropetrovsk region. Report of "Yuzhnukrgeologiya", 2001 2006], Dnipro.

Mokritskaya, T. P., 2013. Formirovaniye i evolyutsiya geologicheskoy sredy Pridneprovskogo promyshlennogo regiona. [Formation and evolution of the geological environment of the Pridneprovsky industrial region]. Dnipropetrovsk, Accent, 274 p. (in Russian).

Mokritskaya, T.P., Fundovaya V.V., 2016. Tendentsii dinamiki solevogo sostava gruntov zony aeratsii gorodskikh prirodnotekhnicheskikh sistem na primere territorii g. Dnepr Trends in the dynamics of the salt composition of soils in the zone of aeration of urban natural-technical systems by the example of the territory of the Dnieper.]. Bulletin of the University of Dnepropetrovsk. Series: geology, geography. 24, 129-136 (in Russian).

Mokritskaya, T. P., Koriashkina L. S. 2013. Degradation in loesses; factors and models. Scientific Bulletin of National Mining University, 4, 5 - 12.

Phillips, T., 2008. Solar Cycle 24 Begins. Retrevied from: https://science.nasa.gov/science-news/science-atnasa/2008/10jan_solarcycle24. бзор состояние солнечной ктивности. 2010. Retrevied from: http://www.izmiran.ru/services/saf/archive/ru/2010/obzor20100207.txt

Hervas, J., Barredo, J.I., Rosin, P.L., 2003. Monitoring landslides from optical remotely sensed imagery: the case history of Tessina landslide, Italy. Geomorphology. Vol. 54, 63-75.

Marcelino, E., Formaggio, A., Maeda, E.,2009. Landslide inventory using image fusion techniques in Brazil. International Journal of applied Earth observation and geoinformation. P. 181-191.

Fernández, T.,Jimenez, J., Fernandez, P., 2008. Automatic Detection of Landslide Features with Remote Sensing Techniques in the Betic Cordilleras (Granada, Southern Spain). The International Archives of the Photogrammetry, Remote Sensing and Spatial Information Sciences. Beijing. Vol. XXXVII. Part B8, 351-356.

Barlow, J., Y. Martin, S. Franklin, 2003. Detecting translational landslide scars using segmentation of Landsat ETM and DEM data in the northern Cascade Mountains, British Columbia. Canadian Journal of Remote Sensing. Vol. 29(4), 510-517.

Cheng, K., Wei, C. \& Chang, S., 2004. Locating landslides using multi-temporal satellite images (2004). Advances in Space Research. V. 33. P. 296-301.

Mezughi, T.H., Akhir, J.M., Rafek, A.G., Abdullah, I., 2011. Landslide Susceptibility Assessment using Frequency Ratio Model Applied to an Area along the E-W Highway (Gerik-Jeli). American Journal of Environmental Sciences. 7 (1). P. 43-50.

Kimura, H., Yamaguchi, Y., 2000. Detection of landslide areas using satellite radar interferometry. Photogrammetric engineering \& remote sensing. Vol. $66,3,337-344$.

Blesius, L., Weirich, F., 2009. The use of high-resolution satellite imagery for deriving geotechnical parameters applied to landslide susceptibility. In: Heipke, C., K. Jacobsen, S. Müller, and U. Sörgel (eds.): International Archives of Photogrammetry, Remote Sensing and Spatial Information Sciences Vol, XXXVIII-1-4-7/W5 International Society for Photogrammetry and Remote Sensing Hannover Workshop 2009 on High-resolution Earth Imaging for Geospatial Information. Hannover, Germany.

Lin, B., Leung, W.Y., Chi, I., Applying, S.Y., 2011. GIS and Remote Sensing to Simply Estimate Landslide Volume of Typhoon Events in a Watershed. International Conference on Fuzzy Systems and Neural Computing. 136-139.

Purnomo, Y., Pinem, F., 2010. GIS analysis for determining of potential landslide area distribution pattern. A case study in Sumedang regency West Java Indonesia. 1st annual conference of the International society for integrated disaster risk management IDRiM, 63-66.

Saraf, A., Das, J., V. Rawat, V., 2009. Satellite Based Detection of Early Occurring and Co-seismic Landslides. South Asia Disaster Stud (Journal of SAARC Disaster Managment Centre). 47-55. 
Shabi, H., Khezri, S., Ahm, B., Allahvirdiasl, H., 2012. Application of satellite images and fuzzy set theory in landslide hazard mapping in central Zab basin. Journal of applied physics. Vol. 1. Issue 4, 1724.

Delacourt, C., Allemand, P., Bertheir, E., 2007. Remotesensing techniques for analysing landslide kinematics: a review (2007). Bull. Soc. Geol. FR.178(2), 89- 100. doi:10.2113/ gssgfbull. 178.2.89.

D. Sudhakar, E. Sumant, S. Suchitra, 2013. Landslide hazard assessment: recent trends and techniques.(2013). Springer Plus. doi:10.1186/21931801-2-523/
Nilanchal, P., Gadadhar, S., Anil Kumar, Sing Manibhushan., 2013. Jmage Classification for Different Land Use and Land Covers Using Fuzzy Logic for the Improvement of Accuracies. Journal of Agricultural Science. 278-283.

Montoya-Montes, I., Rodríguez-Santalla, I., SánchezGarcía, MJ., 2012. Mapping of landslide susceptibility of coastal cliffs: the Mont-Roig del Camp case study. Geologica Acta. Vol. 10, 4, 439-455.

Jef Caers, 2011. Modeling Uncertainty in the Earth Sciences. JohnWiley \& Sons Ltd., 224.

Zuska, A.V., 2014. Kinematicheskaya model' opolznevykh sklonov. [Kinematic model of landslide slopes.] D.: NSU, 1-140 (In Ukrainian). 